\title{
MORPHOLOGY, PHYSIOCHEMICAL CHARACTERISTICS, AND FERTILITY OF SOILS FROM QUATERNARY LIMESTONE IN LEYTE, PHILIPPINES
}

\author{
Victor B. Asio', Carlito C. Cabunos Jr.1, and Zuens-Sans Chen²
}

Very few studies have been conducted on the nature and characteristics of soils from Quaternary limestones in geologically young islands in the humid tropics. This study examined a hillslope in Leyte, Philippines, with soils from Quaternary (Late Pleistocene) limestone and evaluated their morphology, physiochemical characteristics, and fertility constraints. We evaluated six pedons representing different slope positions, such as summit, shoulder, upper backslope, middle backslope, lower backslope, and footslope. Our data indicate that the soils in the upper slopes (summit, shoulder, and upper backslope) have thin solum, black surface horizon, clayey texture, granular structure, high organic matter and $\mathrm{N}$, high $\mathrm{Ca}$ and $\mathrm{CaCO}_{3}$ contents, low contents of nutrients like $\mathrm{P}, \mathrm{K}, \mathrm{Fe}, \mathrm{Mn}$, and $\mathrm{B}$, and are neutral to alkaline $\mathrm{pH}$ values. According to Soil Taxonomy, the soils are classified as Typic Calciudolls (summit) and Rendollic Eutrudepts (shoulder and upper backslope), but all three pedons are classified as Calcaric Phaeozems in the World Reference Base system. Conversely, the soils on the lower slopes (footslope and middle and lower backslopes) have thicker solum and higher clay content. They have subangular blocky structures, which turn hard when dry and become plastic and sticky when wet. Like the soils on the upper slopes, they also have neutral to strongly alkaline $\mathrm{pH}$ values, have high organic matter, $\mathrm{N}, \mathrm{Ca}$, and $\mathrm{CaCO}_{3}$ contents, but are generally low in nutrient contents. They are classified as Typic Eutrudepts (source, Soil Taxonomy) or Calcaric Cambisols (source, World Reference Base). Most soils have high rock fragment contents in their profile. Results also show substantial variations of solum depth at short distances along the slope (i.e., from summit to footslope) and across the slope. The solum depth variability helps explain the commonly observed variations of crop growth in limestone areas. The high clay content of these relatively young soils suggests contribution from limestone parent material and possibly volcanic ash from past eruptions of nearby volcanoes. Our results show that soils developed from limestone have both physical and chemical fertility constraints to upland crop production, which differ between soils even in the same landscape. The overall results indicate that the characteristics and fertility constraints of soils from Quaternary limestones in our study site are largely the influence of the slope position, chemical characteristic of the limestone parent material, and human activities. (Soil Science 2006;171: 648-661)

Key words: Quaternary limestone, tropical islands, soil characteristics, soil fertility constraints, tropical soils, calcareous soil.

'Soil Science Division, Department of Agronomy and Soil Science, Leyte State University, Baybay, Leyte, Philippines. Dr. Victor B. Asio is the corresponding author. E-mail: vbasio_ph@yahoo.com

2Department of Agricultural Chemistry, National Taiwan University, Taipei, Taiwan. Received June 24, 2005; accepted March 1, 2006.

DOI: 10.1097/01.ss.0000228036.72647.e7
C OMPARED with the tropical soils in geologically older regions like Africa and the Americas, less pedological research has occurred on the much younger soils on the islands of Southeast Asia (see Sanchez, 1976; Juo and Franzluebbers, 2003). These soils may be 
distinct from those in other humid tropical areas because of the unique environmental factors that influenced their formation. Geologically, much of Southeast Asia was the result of recent Cenozoic tectonic events, and many areas emerged from the sea recently (Hall, 2002). This has resulted in the formation of relatively young volcanic and sedimentary landforms (e.g., karst) common around the region. In addition, during the drier period of the Quaternary, the effects of climatic changes on landform development were unique in this region because large areas were under the regime of the monsoonal system (Verstappen, 1997). The present climate that prevails in Southeast Asia is also unique in the sense that it is located in the transitional region between the boreal summer Asian monsoon and the boreal winter Asian monsoon (Chang et al., 2005). Biodiversity, which is related to soil processes (Heemsbergen et al., 2004), is high in the region (Myers et al., 2000) because of the effects of climate and geologic history (Nakashizuka, 2004). For instance, the Philippines has been declared as the second "hottest" of the world's biodiversity hotspots (Myers et al., 2000). This means that the Philippines is second only to Madagascar in concentration of endemic plant and vertebrate species and habitat loss. However, during the last several decades, logging, shifting cultivation, increased upland population, and unsuitable land use systems have caused widespread degradation of upland areas in the Philippines and other parts of Southeast Asia (for examples, see Scholz, 1986; Asio, 1998).

Quaternary limestones are widespread in the islands of Southeast Asia and other tropical regions (for examples, see FAO-UNESCO, 1979). Because of high initial crop productivity and easy accessibility due to generally near or along the coast location and low elevation, limestone areas have a long history of cultivation and other anthropogenic influences, resulting in widespread land degradation (for examples, see Urich et al., 2001; Day and Chenoweth, 2004). Thus, there is a need for studies on the nature and characteristics of these soils for their sustainable management for agriculture or rehabilitation by reforestation or agroforestry. Such studies will also contribute to our better understanding of soils on young tropical islands. We are not aware of any published studies dealing with the characteristics and fertility of soils on Quaternary limestones from the Philippines or any other island in Southeast Asia. In fact, limited studies have been conducted in other regions also. Rabenhorst et al. (1991) noted that although limestones are quite extensive on a worldwide scale, pedologists have directed less attention toward them. Ironically, the scientific literature abounds with agronomic and plant nutrition studies related to the alleviation of one or a few mineral nutrient problems in calcareous soils (see Mengel and Kirkby, 2001; Braschi et al., 2003).

Studies from other areas have shown that soils from limestones vary from calcareous and shallow young soils to acidic and deep old soils (Legros, 1992; Buol et al., 1997; Muhs, 2001). However, the occurrence of relatively young clayey soil on limestone is, until now, poorly understood. Legros (1992) suggested two hypotheses regarding its origin. The first states that the soil comes from the residue after the carbonate has dissolved; the second states that the soil comes from eolian dust. Other possible sources of clay include fine clay illuviation and clay deposition by fluvial and colluvial processes. In his study on the soils on Quaternary reef terraces in Barbados, Muhs (2001) concluded that the soils were developed from dust derived from the Sahara, volcanic ash from the Lesser Antilles island arc, and detrital carbonate from the underlying reef limestone.

The foregoing review has shown that our understanding of soils on tropical islands in Southeast Asia and of soils from Quaternary limestone is limited despite their widespread occurrence and agricultural importance in the region (limestone areas are estimated to occupy $35,000 \mathrm{~km}^{2}$ in the Philippines alone [SWCFCFTU-IGCI, 2005]). Thus, this study was conducted to evaluate the morphology, physiochemical characteristics, and fertility constraints of soils from Quaternary (Late Pleistocene) limestone in Leyte, Philippines.

\section{MATERIALS AND METHODS}

\section{Study Site}

The study site is located in a limestone hill along the west-facing coast of Punta, Baybay, Leyte, Philippines (Fig. 1). The hill seems to be a remnant of a reef terrace produced by tectonic uplift. It is underlain by marly limestone up to a height of about $50 \mathrm{~m}$ above sea level, and then by coralline limestone up to the summit of $80 \mathrm{~m}$ above sea level. In the absence of actual data on the age of the terrace, we estimate its age to be 


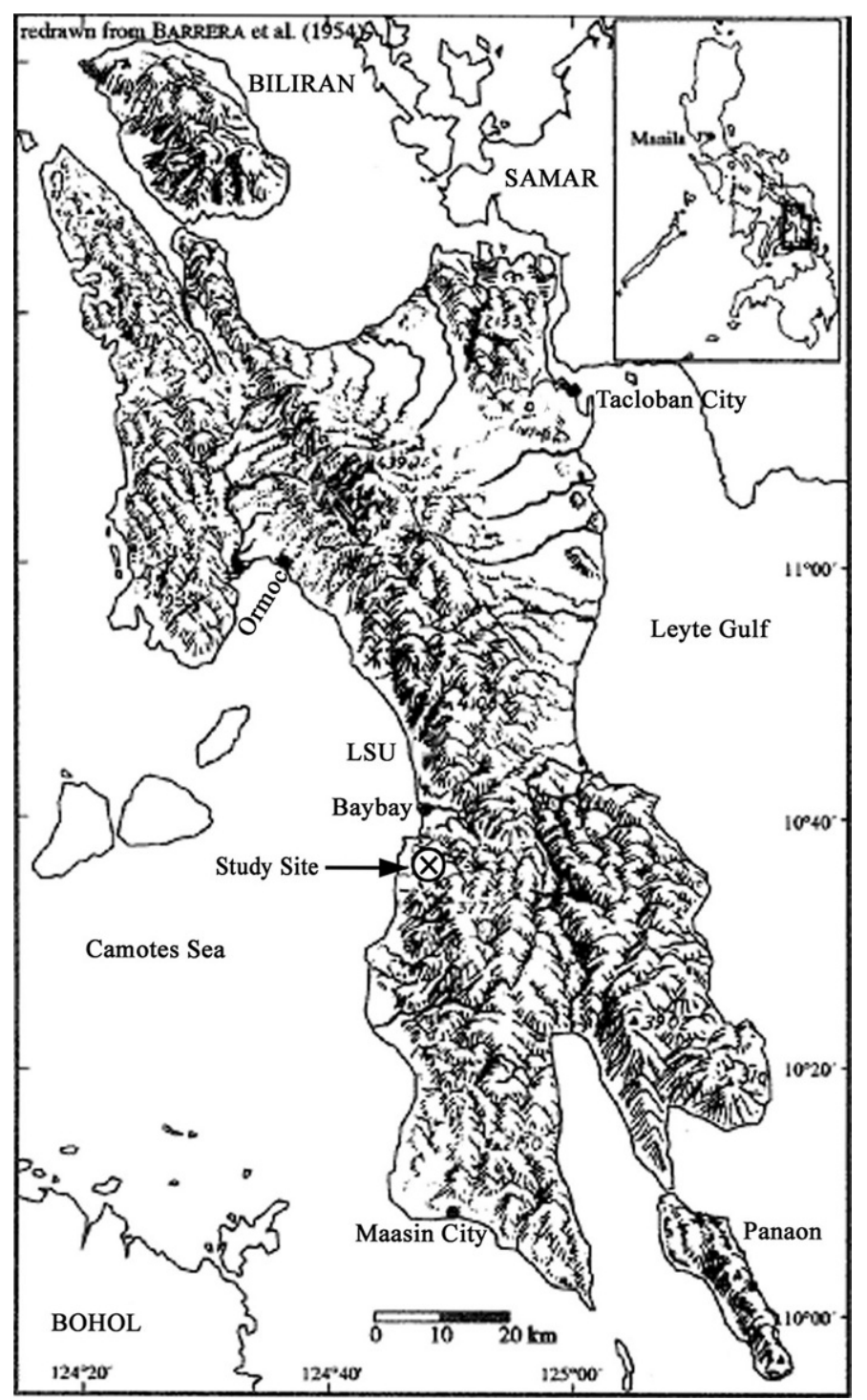

Fig. 1. Location of study site in Leyte, Philippines.

between 100 and 200 kyr B.P. on the basis of radiometric dating $\left(230^{\mathrm{Th}} / 234 \mathrm{U}\right)$ studies on Pleistocene coral reef terraces in the nearby opposite islands of Bohol and Cebu (Omura et al., 2004), although soil development seems to be much younger, probably because of erosion and deposition processes in the past. The topography of the site ranges from moderately sloping to rolling. The original vegetation was dipterocarp rain forest, whereas the present land use is a mosaic of grass fallow (mainly Panicum maximum and Imperata cylindrica), shrubland, sparse stand of stunted coconut trees, fruit trees, and upland farms planted with corn and root crops, such as cassava and sweet potatoes. Punta was one of the first places to be inhabited by Spaniards when they came to Leyte in the 17th century (Mollaneda, 1988), implying that the area has a long history of anthropogenic influence. This explains the degraded nature of the landscape. According to the Köppen classification (Köppen, 1923), the climate of Leyte is humid tropical monsoon characterized by an average annual rainfall of $2800 \mathrm{~mm}$, with no distinct dry season and with an average temperature of $28{ }^{\circ} \mathrm{C}$. Two monsoonal winds blow in Leyte and in other parts of the archipelago (Coronas, 1920). From May to October, there is 
present) was noted from each pedon and from 2 to 4 points between the pits along the catena, with the aid of a soil auger (interval between points, $\approx 5-10 \mathrm{~m}$ ). Moreover, we were also able to evaluate the solum depth variations across the slope using the soil trench constructed by the World Agroforestry Center (ICRAF) researchers in the middle backslope position for soil erosion measurement (in relation to their agroforestry trial). The trench, which was about $40 \mathrm{~m}$ long and 80 to $100 \mathrm{~cm}$ deep, provided a good opportunity to measure the solum depth variation at the meter scale.

\section{Laboratory Analysis}

Particle size distribution was analyzed by the pipette method after pretreatment of soil samples with $\mathrm{HCl}$ and $\mathrm{H}_{2} \mathrm{O}_{2}$ to remove carbonates and organic matter $(\mathrm{OM})$, respectively (Schlichting et al., 1995; USDA-NRCS, 1996). Bulk density was determined by taking three soil cores from each horizon according to Schlichting et al. (1995). Soil pH was determined potentiometrically using water and $0.01 \mathrm{~mol} / \mathrm{L} \mathrm{CaCl}_{2}$ at a soil-solution ratio of 1:2.5 (ISRIC, 1995); OM and total $\mathrm{N}$ using modified Walkley-Black and modified Kjeldhal methods, respectively (USDA-NRCS, 1996); available phosphorus using $\mathrm{NaHCO}_{3}$ at $\mathrm{pH} 8.5$ (Olsen method; ISRIC, 1995); cation exchange capacity (CEC) using $\mathrm{NH}_{4} \mathrm{OAc}$ at $\mathrm{pH} 7$ (USDA-NRCS, 1996); and $\mathrm{CaCO}_{3}$ equivalent using the gravimetric procedure based on the reaction of $\mathrm{CaCO}_{3}$ with HCl (Loeppert and Suarez, 1996). Exchangeable $\mathrm{K}$, $\mathrm{Ca}, \mathrm{Na}$, and $\mathrm{Mg}$ were extracted by using $\mathrm{NH}_{4} \mathrm{OAc}$ (hydrogen ion concentration, $\mathrm{pH}$ 7; USDA-NRCS, 1996); Fe, Mn, and Zn by using diethylenetriamine pentaacetic acid-triethanolamine (Martens and Lindsay, 1990); and B by hot water extraction method (Johnson and Fixen, 1990), and then quantified by atomic absorption spectrophotometry. Total $\mathrm{Fe}$ and $\mathrm{Zn}$ contents of plant leaf samples collected from the site were determined by dry-ashing procedure and then quantified by atomic absorption spectrophotometer (Westerman, 1990).

\section{RESULTS AND DISCUSSION}

\section{Morphophysical Characteristics}

Results revealed considerable variations in the morphological and physical characteristics of the soils from Quaternary limestone, depending on their geomorphic position in the study site
(Table 2). Soils in the upper slopes (pedons 1, 2, and 3) are more poorly developed, as indicated by their AC profiles. They have thin solum (depth, 15-26 cm), abundant rock fragments, strong granular structure on their A horizons, making them loose and friable, and subangular blocky structure in their subsoils. On the other hand, the soils on the lower slopes (pedons 4, 5, and 6) are more developed, as shown by their A-Bw-C profiles. They also have substantially thicker solum (depth, 35-70 cm) with moderately developed $\mathrm{B}$ horizons and subangular blocky structures on both the surface and the subsurface horizons (Fig. 3A). However, all soils have high clay content (composition, $>40 \%$ ) in the fine-earth fraction, although those on the lower slopes seemed to have generally higher clay and silt contents than those on the upper slopes (Fig. 2). In addition, they all have black (color, 10YR 2/1) A horizons and brown to very pale brown (color, 10YR 4/3 to 10YR 8/4) $\mathrm{B}$ and $\mathrm{C}$ horizons. The stark contrast between the colors of the surface and the subsurface horizons is very clear in the field, especially on nonvegetated areas. All soils become plastic and sticky when wet but turn very hard when dry (except the A horizons of the soils on the upper slopes).

Results showed that solum thickness in the study site varies greatly along the slope (i.e., from the summit to the footslope; Fig. 3A) and across the slope, on the basis of our examination of a portion of the middle slope with uniform topography (Fig. 3B). As can be seen from Fig. 3A, the thinnest solums are found on the shoulder and upper backslope positions, whereas the thickest can be seen in the lower backslope position.

The results generally agree with the literature stating that soils from limestone vary from poorly developed to well-developed soils (Legros, 1992; Buol et al., 1997; Day and Chenoweth, 2004). The differences in profile development and morphological and physical properties of the soils in our study site seem to be largely the effect of parent material, relief, and anthropogenic factors. For instance, the generally thinner solum of the soils on the upper slopes reflects the influence of slope on water movement, which, in turn, determines the rates of weathering, erosion, and soil formation (Johnson, 1985; Sommer and Schlichting, 1997; Chen et al., 1999). Thus, slope positions, which enhance very high runoff and erosion, such as the shoulder and upper slope, produced 


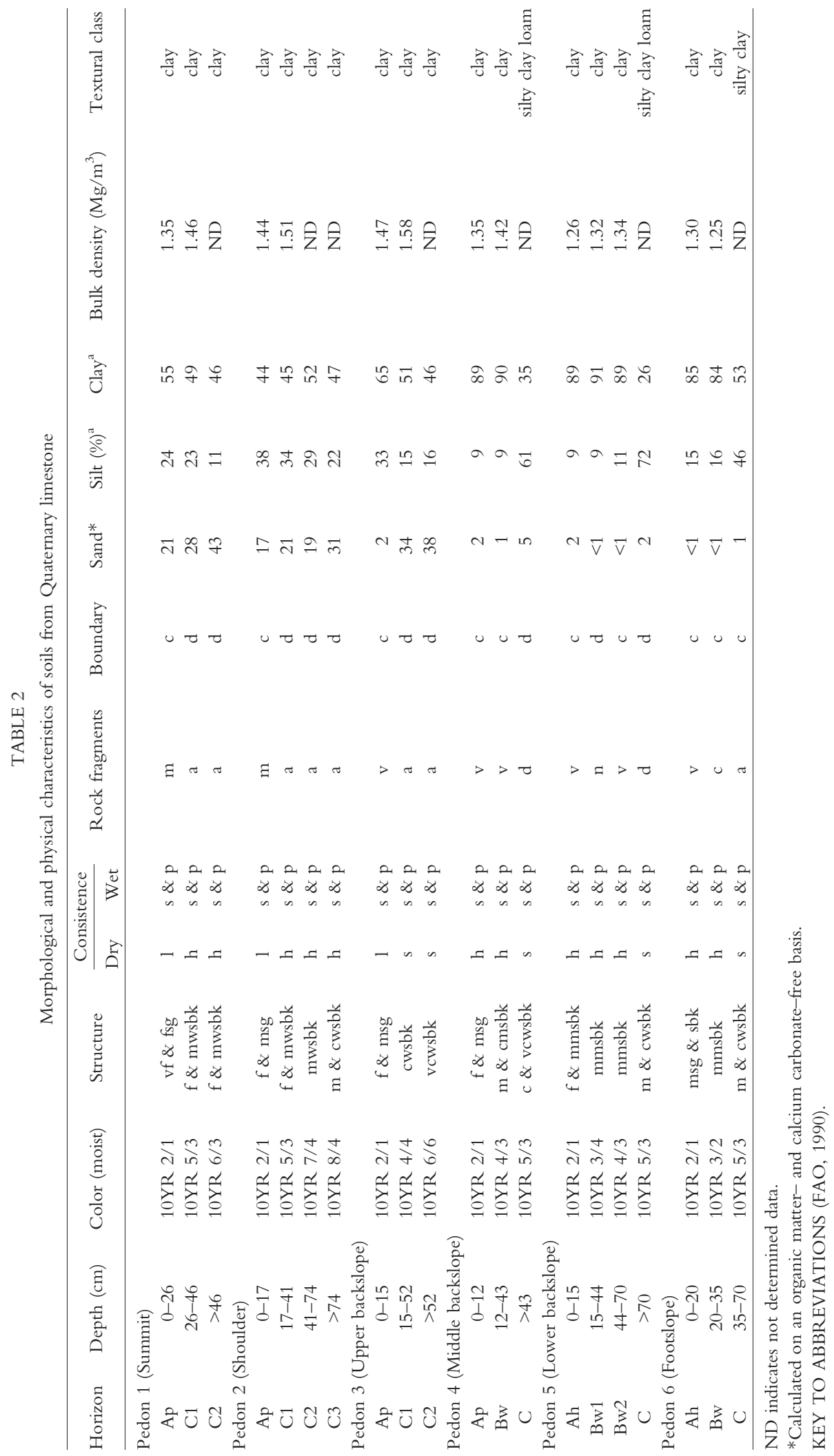




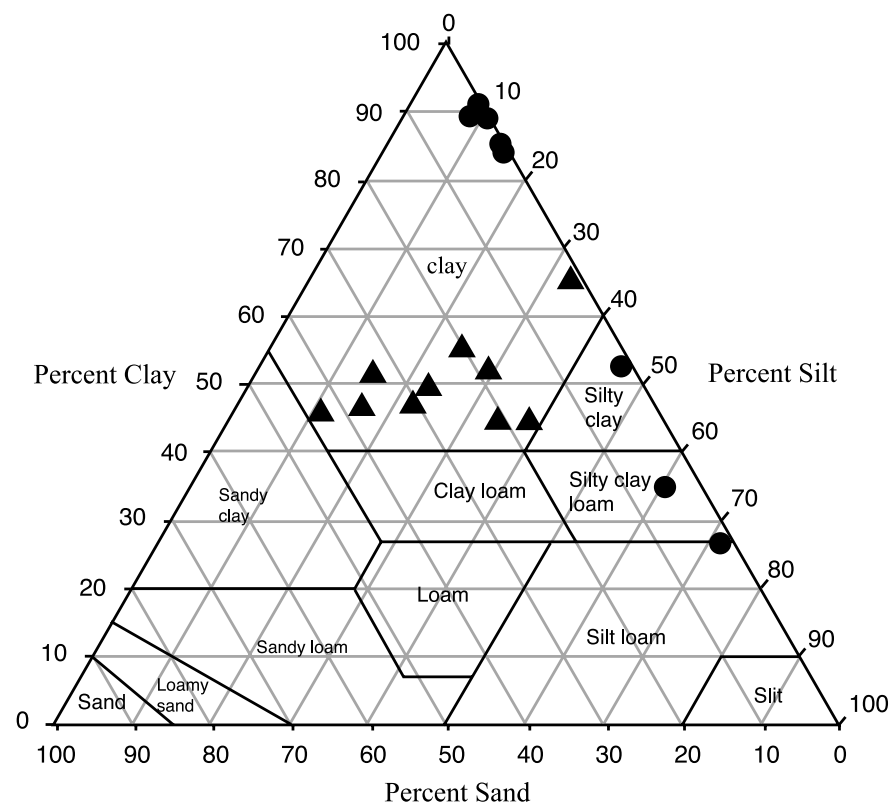

A Upper slope soils (pedons 1, 2, 3)

- Lower slope soils (pedons $1,2,3$ )

Fig. 2. Particle size distribution and textural classes of each sampled horizon of the pedons studied based on the USDA textural triangle.
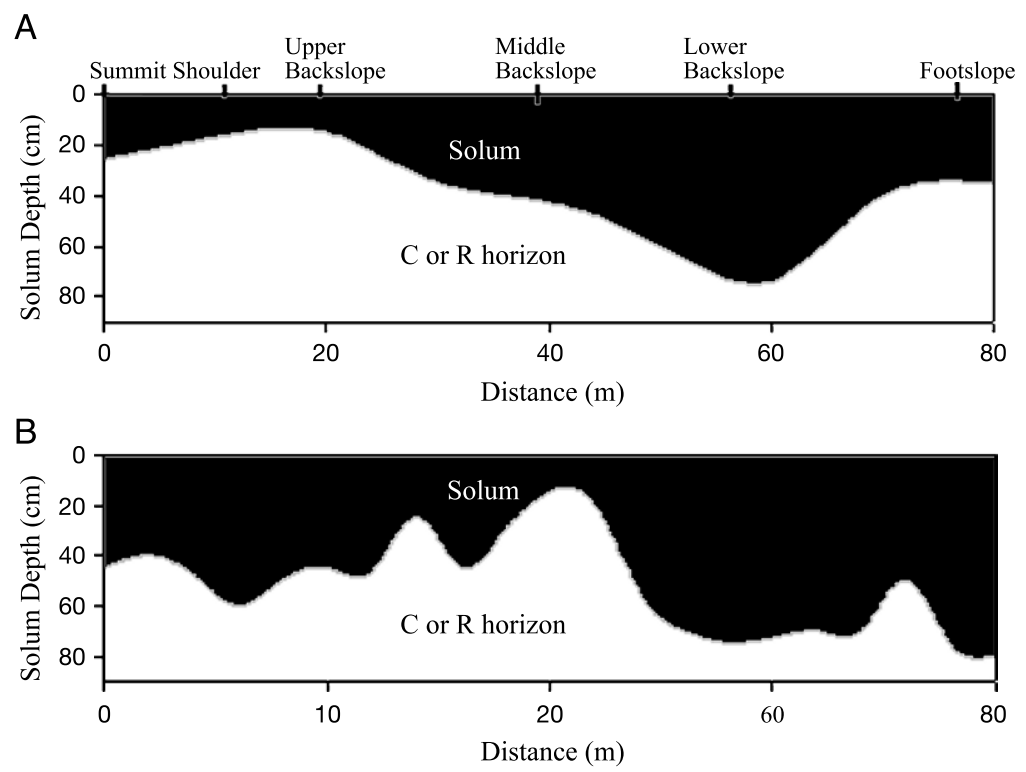

Fig. 3. Variations of solum depth of soils from Quaternary limestone. A, Along the slope from summit to footslope (range, 15-70 cm; mean, $34.7 \mathrm{~cm}$; SD, 17.7, coefficient of variation, $50.9 \% ; n=18$ ). $B$, Across the slope on a relatively level area in the middle backslope position (range, $15-80 \mathrm{~cm}$; mean, $51.5 \mathrm{~cm}$; SD, 18.5; coefficient of variation, $35.9 \% ; n=21$ ). 
the thinnest solum. On the other hand, the lower backslope and footslope positions, which are less subject to erosion and allow for more downward water movement and deposition of surficial materials coming from the upper slopes, showed the thickest solum. The influence of parent material on solum thickness is also evident. The soil on the upper slopes was derived from coralline limestone, whereas the soil on the lower slopes developed from marly limestone; marly limestone contains more fine particles (silt and clay) but slightly lesser calcium carbonate content than does coralline limestone. The higher fine particles content of marly limestone also helps explain the higher clay content of the soils derived from it. The long history of anthropogenic influence in the area may also have contributed to the thinness of solum, especially of the soils on the upper slopes because of enhanced erosion, mixing, and other soil processes. Kleber et al. (2003) have observed the significant role of human influence in changing and slowing down soil development.

The considerable differences in solum thickness at short distances across the slope can be due to the differential solubility of the limestone parent material, as can be observed on limestone outcrops in nearby areas. Soft portions of limestone dissolve easily, resulting in depressions that later become filled with soil (Legros, 1992). The further deepening of the depression, which usually leads to the formation of sinkholes, is enhanced because of the much faster dissolution of limestone when covered with soil than when bare (Urushibara-Yoshino et al., 1999). Such solum thickness variability of soils from limestone has important ecological implications. It helps explain the commonly observed differences in the growth of crops on limestone sites even in areas with uniform surface topography, as we have observed in our study site. Moreover, it may enhance the development of a diverse group of natural vegetation species and soil fauna (Anonymous, 1999).

The black color of the surface horizons with granular structure is related to their high OM content. A comparable soil color (10YR 3/2) was observed on the surface horizons of soils on reef terraces in Barbados (Muhs, 2001). The hard consistency when dry and the plastic and sticky consistency when wet suggests the presence of smectite silicate minerals in the clay fraction. Regarding the high clay contents of the soils, Muhs (2001) attributed the high clay content of the soils on limestone in Barbados to have come from dust, volcanic ash, and detrital carbonate from the underlying reef limestone. Similarly, the very high clay content of these relatively young soils that we have studied may have been derived from the limestone rock and from eolian addition, particularly volcanic ash. If our estimate of the age of the terrace is correct, which is between 100 and 200 kyr B.P., it puts the origin of the terrace in the Pleistocene epoch, at which time major volcanic eruptions produced the widespread Pleistocene volcanic rocks in the nearby central highlands of Leyte (DENR, 1992; Asio, 1996). Moreover, the marly limestone in the lower part of the catena may have also derived much of its fine particles from volcanic ash.

\section{Chemical Characteristics}

Compared with the morphological and physical properties, less dramatic variations in soil chemical properties with landscape position can be seen in Table 3. All soils have high $\mathrm{pH}_{\mathrm{H}^{2} \mathrm{O}}(>7.2)$, with the general tendency to be slightly higher in the subsurface than in the surface horizons. As expected, $\mathrm{pH}$ in $\mathrm{CaCl}_{2}$ is lower than $\mathrm{pH}_{\mathrm{H}^{2} \mathrm{O}}$ in all soils. OM and total $\mathrm{N}$ contents are high in the $\mathrm{A}$ horizons and then abruptly decrease with depth, whereas available $\mathrm{P}$ and extractable $\mathrm{Fe}, \mathrm{Mn}$, and $\mathrm{B}$ contents are low in all soils. Available $\mathrm{P}$, exchangeable $\mathrm{K}$ and $\mathrm{Mg}$, and extractable Fe contents tend to increase from the soils on the upper slopes to the lower slopes. Exchangeable $\mathrm{Na}$ content is low, whereas $\mathrm{Ca}$ content is very high as expected because of the presence of $\mathrm{CaCO}_{3}$ in the solum. Thomas (1982) stated that no method is satisfactory for exchangeable $\mathrm{Ca}$ in the presence of free $\mathrm{CaCO}_{3}$; hence, the values for $\mathrm{Ca}$ are not reflective of the amount of exchangeable Ca. Cation exchange capacity is high in all soils and seems to be higher in the soils in the lower portion of the profile (pedons 4, 5, and 6). $\mathrm{CaCO}_{3}$ content is very high in all soils, particularly in the subsoils. Fine particles of $\mathrm{CaCO}_{3}$ were observed in the $A$ horizons, whereas a mixture of fine and coarse particles of $\mathrm{CaCO}_{3}$ were observed in the lower horizons during the field examination.

The results suggest that most of the chemical properties of the soils from limestone evaluated are directly related to the nature of the limestone parent material. For instance, the neutral to strongly alkaline $\mathrm{pH}$ values are caused by the high amounts of $\mathrm{CaCO}_{3}$ in the profiles, which, in turn, are inherited from the limestone rock. 


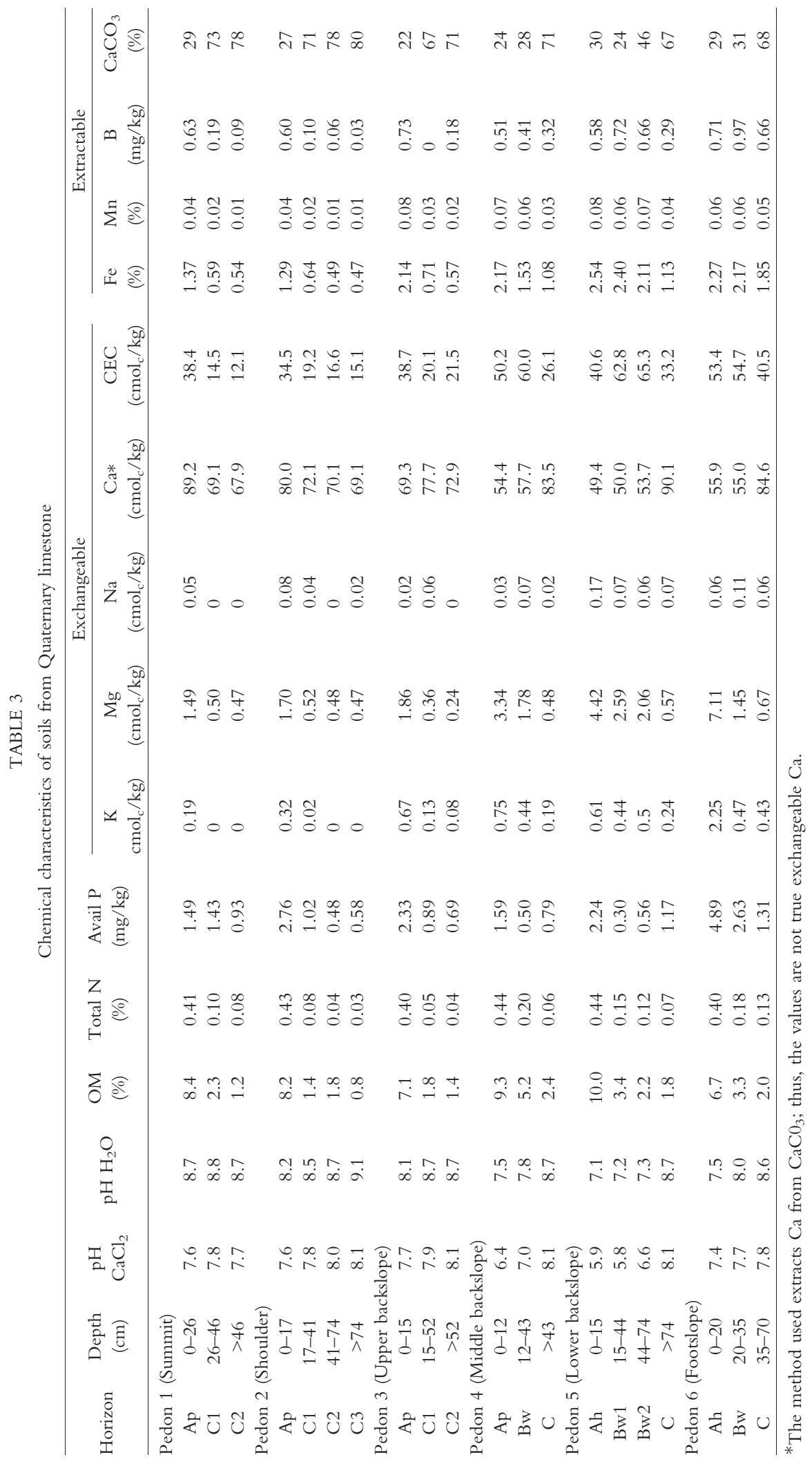


The high $\mathrm{pH}$ values of the soils agree with the hypothesis that soil $\mathrm{pH}$ value does not drop below 7.0 in the presence of $\mathrm{CaCO}_{3}$ because of its buffering capacity (Ulrich, 1986). Loeppert and Suarez (1996) likewise reported that the $\mathrm{pH}$ values of most calcareous soils are within the range 7.5 to 8.5 . The high $\mathrm{OM}$ content of the surface horizons, which is associated with granular structure and dark color of the soil, is ascribable to the preservation of OM by high $\mathrm{Ca}$ (Legros, 1992). The low available P, extractable $\mathrm{Fe}, \mathrm{Mn}$, and $\mathrm{B}$ contents are due to the alkaline condition of the soil, which causes precipitation of these elements, and probably to the low inherent contents in these elements of the parent limestone rock. The tendency for $\mathrm{K}$ and $\mathrm{Mg}$ contents to increase from the summit to the footslope suggests possible downslope movement of these materials due to water movement (Sommer and Schlichting, 1997; Tsui et al., 2004). Hence, the sequence of soils we evaluated can be considered as a translocation catena, according to the classification of Sommer and Schlichting (1997). The low exchangeable $\mathrm{Na}$ content of the soils reflects the low amount of this element in the parent rock, but the slight tendency for it to be higher on the surface soil may be caused by salt spray from the sea. In his study in the nearby island of Samar, Navarrete (2002) observed much higher amounts of exchangeable $\mathrm{Na}$ in soils near the coast than in another comparable soil several kilometers inland. Yaalon (1983) has suggested the important role of salt spray in soil development for coastal areas. The high CEC is related to the high amount of clay of the soils. The occurrence of substantial amounts of fine particles of $\mathrm{CaCO}_{3}$ in the solum contradicts the report of Legros (1992) and could be due to the mixing effect of frequent cultivation. We observed that coarse fragments of partially weathered limestone materials from the $\mathrm{C}$ horizon are brought, in many instances, into the soil surface after plowing with animal-drawn implements.

\section{Soil Classification}

According to Soil Taxonomy (Soil Survey Staff, 1999), the soil in the summit (pedon 1) is classified as Typic Calciudoll, implying that it has friable dark surface horizons due to high humus content but has, at the same time, high calcium carbonate content and is poorly developed. The soils in the shoulder and upper backslope positions (pedons 2 and 3) failed the soil depth requirement for the mollic epipedon, although they also possess the other morphological features of the said diagnostic horizon. Thus, they are classified as Rendollic Eutrudepts, reflecting the free carbonates, which are more than $40 \%$, in their solum. The soils on the middle backslope, lower backslope, and footslope (pedons 4, 5, and 6) are classified as Typic Eutrudepts. According to Soil Taxonomy (Soil Survey Staff, 1999), Eutrudepts are base-rich Udepts of humid areas developed in Holocene or Late Pleistocene deposits, some of which have steep slopes and calcareous parent materials. In the WRB (1998) classification system, the upper three soils are classified as Calcaric Phaeozems, whereas the lower three soils are Calcaric Cambisols. The differences in soil characteristics, primarily caused by the controlling effect of parent material and relief position, resulted in different soil taxa.

\section{Soil Fertility}

In view of the fact that soils from limestones are widely used for upland crop production in the Philippines, particularly for corn, root crops like sweet potato and cassava, coconut, and mango, we evaluated the fertility status of the five pedons by matching the values of selected soil properties with published threshold values of the same properties for crop growth or crop production (Tisdale et al., 1985; Landon, 1991; Schlichting et al., 1995). This matching process enables one to identify potential soil fertility constraints to the production of agricultural crops, and thus provides valuable information for the design of appropriate soil management strategies for the sustainable crop production, especially in problem soils such as in our study site. This is in accord with the suggestion that careful assessment of soil constraints is one of the priorities to sustain agricultural production in the tropics (Lal and Ragland, 1993; Lal, 2000).

Table 4 shows that the soils in different slope positions in the study site vary in their fertility characteristics on the basis of the presence or absence of soil fertility constraints. Shallow depth is a constraint in the soil in the upper slopes (pedons 1,2, and 3), but not in the thicker soils in the lower portion. The clayey texture coupled by blocky structure that turns hard upon drying is a limitation for the soils on the lower slopes, but not for those on the upper slopes because of the good granular structure. The sticky and plastic consistency of the soils on the lower slope is a problem for farm operations 
TABLE 4

Fertility constraints to crop production of soils from Quaternary limestone based on the properties of surface horizons*

\begin{tabular}{|c|c|c|c|c|c|c|c|}
\hline Soil properties & Threshold pedon value $e^{\dagger}$ & \multicolumn{6}{|c|}{ Pedon } \\
\hline Depth $(\mathrm{cm})^{*}$ & $>50$ & - & - & - & + & + & + \\
\hline Bulk density $\left(\mathrm{g} / \mathrm{cm}^{3}\right)^{\|}$ & $<1.45$ & + & + & + & + & + & + \\
\hline Consistence & fr, np, ns & + & + & + & - & - & - \\
\hline Total N $(\%)^{\pi}$ & $>0.2$ & + & + & + & + & + & + \\
\hline Avail. P (mg/kg) & $>8-15$ & - & - & - & - & - & - \\
\hline Exch. K (cmol/ kg) & $>0.20$ & - & - & - & - & - & - \\
\hline Exch. Ca $(\mathrm{cmol} / \mathrm{kg})^{ף}$ & $>0.40^{\#}$ & - & - & - & - & - & - \\
\hline Ext. B $(\mathrm{mg} / \mathrm{kg})^{t+}$ & $>1.00$ & - & - & - & - & - & - \\
\hline
\end{tabular}

Plus sign $(+)$ indicates that soil property is favorable for crop growth; minus sign $(-)$, soil property is a constraint to crop growth/crop production; fr, friable; np, nonplastic; ns, nonsticky.

*Except for depth, which considers solum thickness.

†It can also be called "favorable value or condition."

* Based on Schlichting et al. (1995).

${ }^{\S}$ Based on Landon (1991). Clay texture with granular structure is favorable.

"Based on Arshad et al. (1996).

"Based on Landon (1991).

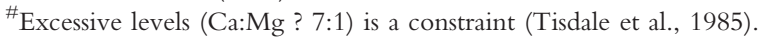

**Based on Haby et al. (1990).

${ }^{\dagger}$ Based on Martens and Lindsay (1990).

**Based on Johnson and Fixen (1990).

during dry periods and in the rainy season. This was confirmed by our observations and interviews with farmers in the area. Because of the high $\mathrm{CaCO}_{3}$ content, the $\mathrm{pH}$ level is also a constraint, in addition to the deficiency of the mineral nutrients $\mathrm{P}, \mathrm{K}, \mathrm{Fe}, \mathrm{Mn}$, and $\mathrm{B}$. Braschi et al. (2003) reported that the precipitation of insoluble $\mathrm{Ca}-\mathrm{P}$ phases is the predominant process that reduces $\mathrm{P}$ availability to plants for calcareous soils with a large reservoir of exchangeable $\mathrm{Ca}$. Our field observations of mango and coconut plants growing in the site revealed serious nutritional problems, with $\mathrm{Fe}$ deficiency being the most obvious, as indicated by chlorotic leaves. This was confirmed by our analysis of leaf samples of mango and coconut, which revealed Fe contents of 34 and $42 \mathrm{mg} / \mathrm{kg}$, respectively. Both values are below the critical level of 50 to $150 \mathrm{mg} / \mathrm{kg}$ Fe in plants (Marschner, 1995). Mengel and Kirkby (2001) mentioned that high bicarbonate concentration from the dissolution of $\mathrm{CaCO}_{3}$ in calcareous soils induces $\mathrm{Fe}$ chlorosis in plants growing in such soil. Srivastava and Gupta (1996) revealed that $\mathrm{Mn}$ is also tightly fixed on the surface of $\mathrm{CaCO}_{3}$ particles by adsorption. Likewise, the presence of free $\mathrm{CaCO}_{3}$ increases the retention of $\mathrm{B}$ but reduces its availability because of precipitation reaction. Excess $\mathrm{Ca}$ in the soil is also a constraint because when $\mathrm{Ca} / \mathrm{Mg}$ ratio exceeds $7: 1, \mathrm{Mg}$ becomes deficient (Tisdale et al., 1985). Our analysis of leaf samples of mango and coconut indicated that these plants have Zn deficiency, as revealed by their $\mathrm{Zn}$ contents (10 and $9 \mathrm{mg} / \mathrm{kg}$, respectively), which are below the critical level of 15 to $20 \mathrm{mg} / \mathrm{kg}$ (Marschner, 1995). $\mathrm{Zn}$ is deficient in calcareous soil because it is adsorbed on carbonates (Tisdale et al., 1985; Mengel and Kirkby, 2001).

The results indicate that most of the fertility constraints of the soils studied are directly or indirectly related to the nature and characteristics of the limestone parent material. Moreover, the results indicate that limestone soils in the landscape could vary in their fertility status because of variations in the characteristics of the parent material, slope position, and anthropogenic influence. Contrary to common notion, calcareous limestone soils also have physical fertility constraints (see Lal, 2000) aside from 
the nutrient imbalances associated with the alkaline $\mathrm{pH}$. Our results thus imply that agronomic and plant nutrition research, which focuses on only one or two deficient mineral nutrients in calcareous soils, as is commonly practiced, is too simplistic and will contribute little for the sustainable crop production in such soils. Soil management strategies should consider the physical and chemical characteristics and the site conditions. Lal (2000) stressed that soil management should be based on a holistic approach to solve practical problems.

\section{CONCLUSIONS}

From the results of this study, the following conclusions may be drawn:

The characteristics of the soils from Quaternary limestone vary with slope position. Those on the upper slopes (summit, shoulder, and upper backslope) have thin solum, black surface horizon, clayey texture, granular structure, high $\mathrm{OM}$ and $\mathrm{N}$, high $\mathrm{Ca}$ and $\mathrm{CaCO}_{3}$ contents, low contents of other nutrients like $\mathrm{P}, \mathrm{K}, \mathrm{Fe}, \mathrm{Mn}$, and $\mathrm{B}$, and are neutral to alkaline $\mathrm{pH}$ values. Conversely, the soils on the lower slopes (footslope and middle and lower backslopes) have thicker solum and higher clay content subangular blocky structures that turn hard when dry and become plastic and sticky when wet. They also have neutral to strongly alkaline $\mathrm{pH}$ values, high $\mathrm{OM}, \mathrm{N}, \mathrm{Ca}$, and $\mathrm{CaCO}_{3}$ contents, and are also generally low in the content of nutrients, particularly $\mathrm{P}, \mathrm{K}, \mathrm{Fe}$, $\mathrm{Mn}$, and B. Most soils have high rock fragment contents in their profile.

The soils possess both physical and chemical constraints to crop production. The most important physical constraints are the shallow depth for the soils on the upper slopes and the plastic and sticky consistence for those on the lower slopes. The chemical constraints, such as the alkaline $\mathrm{pH}$ value, and the deficiencies of nutrients like $\mathrm{P}, \mathrm{K}, \mathrm{Fe}, \mathrm{Mn}$, $\mathrm{B}$, and $\mathrm{Zn}$, are directly related to the calcareous nature of the soils, which, in turn, is closely linked to the chemical characteristic of the limestone parent material.

The soils show substantial variations in solum depth at short distances along the slope (i.e., from summit to footslope) and across the slope, which are probably the effect of the slope position and the differential solubility of the limestone. This solum depth variation has tremendous implication for the use and management of the soils.

The high clay content of the soils suggests a possible eolian contribution, particularly from volcanic ash, considering that the area is close to volcanic mountains. This is in addition to the contribution of the limestone parent material and deposition, particularly for the soils in the lower slopes.

Slope position, chemical characteristic of parent material, and anthropogenic influence (cultivation) seem to be the major factors that contributed to the differences in the characteristics and fertility status among the limestone soils studied.

\section{ACKNOWLEDGMENTS}

The authors thank Dr. Marco Stark, formerly a member of ICRAF, for supporting and encouraging the catena study we conducted in 2001 on which this article was partly based, ICRAF-Visayas for providing partial funding to that study, and the Analytical Service Laboratory of the International Rice Research Institute in Laguna for performing several chemical analyses. We are also grateful to the Leyte State University for funding our Leyte Soil Mapping Project, which enabled us to conduct additional field and laboratory works on the same soils in 2004, Prof. R. Jahn (University Halle, Germany) for some helpful field discussions during the international ecology workshop in Leyte in 2003, Chia-Hsing Lee of National Taiwan University for his help with data processing, and the National Science Council of Taiwan for the funding support, which made the publication of this article possible.

\section{REFERENCES}

Anonymous. 1999. Proceedings of the 10th International Seminar-Workshop on Tropical Ecology, Leyte, Philippines. Ann. Trop. Res. (Phil.) 20: 1-200.

Arshad, M. A., B. Lowery, and B. Grossman. 1996. Physical tests for monitoring soil quality. In: J. W. Doran and A. J. Jones (eds.). Methods for Assessing Soil Quality. SSSA Special Publ. No. 49, Madison, WI, pp. 123-141.

Asio, V. B. 1996. Characteristics, weathering, formation, and degradation of soils from volcanic rocks in Leyte, Philippines. Hohenheimer Bodenkundliche Hefte, Vol. 33, Stuttgart, Germany. 
Asio, V. B. 1998. A review of upland agriculture, population pressure, and environmental degradation in the Philippines. Ann. Trop. Res. (Phil.) 19:1-18.

Braschi, I., C. Ciavatta, C. Giovannini, and C. Gessa. 2003. The combined effect of water and organic matter on phosphorus availability in calcareous soils. Nutr. Cycl. Agroecosys. 67:67-74.

Buol, S. W., F. D. Hole, R. J. McCracken, and R. J. Southard. 1997. Soil Genesis and Classification. 4th ed. Iowa State University Press, Ames.

Chang, C. P., Z. Wang, J. McBride, and C. H. Liu. 2005. Annual cycles of Southeast Asia-maritime continent rainfall and the asymmetric monsoon transition. J. Climate 18:287-301.

Chen, Z. S., V. B. Asio, and D. F. Yi. 1999. Characteristics and genesis of volcanic soils along a toposequence under a subtropical climate in Taiwan. Soil Sci. 164:510-525.

Coronas, J. 1920. The Climate and Weather of the Philippines. Bureau of Print, Manila, Philippines.

Day, M. J., and M. S. Chenoweth. 2004. The karstlands of Trinidad and Tobago, their land use and conservation. Geogr. J. 170:256-266.

DENR, 1992. Geologic map of Leyte. Department of Environment and Natural Resources (DENR), Region VIII, Tacloban City, Philippines.

FAO-UNESCO, 1979. Soil Map of the World 1:5,000,000. Vol. VII. Paris, France.

FAO, 1990. Guidelines for soil description. 3rd ed. Rome, Italy.

Haby, V. A., M. P. Ruselle, and E. O. Skogley. 1990. Testing soils for potassium, calcium, and magnesium. In: R. L. Westerman (ed.). Soil Testing and Plant Analysis. 3rd ed. SSSA, Madison, WI, pp. 181-227.

Hall, R. 2002. Cenozoic geological and plate tectonic evolution of SE Asia and the SW Pacific: model and animation. J. Asian Earth Sci. 20:353-431.

Heemsbergen, D. A., M. P. Berg, M. Loreau, J. R. van Hal, J. H. Faber, and H. A. Verhoef. 2004. Biodiversity effects on soil processes explained by interspecific functional dissimilarity. Science 306 : 1019-1020.

ISRIC, 1995. Procedures for soil analysis. L. P. Reeuwijk (ed.). International Soil Reference and Information Center, Wageningen, The Netherlands.

Johnson, D. L. 1985. Soil thickness processes. In: P. D. Jungerius (ed.). Soils and geomorphology. Catena suppl. 6, pp. 29-40.

Johnson, G. V., and P. E. Fixen. 1990. Testing soils for sulfur, boron, molybdenum, and chlorine. In: R. L. Westerman (ed.). Soil Testing and Plant Analysis. 3rd ed. SSSA, Madison, WI, pp. 265-271.

Juo, A. S. R., and K. Franzluebbers. 2003. Tropical Soils: Properties and Management for Sustainable Agriculture. Oxford Univ. Press, Oxford, England.

Kleber, M., J. Rössner, C. Chenu, B. Glaser, H. Knicker, and R. Jahn. 2003. Prehistoric alteration of soil properties in a central German chernozemic soil: in search of pedologic indicators for prehistoric activity. Soil Sci. 168:292-306.

Köppen, W. S. 1923. Die Klimate der Erde. Walter der Gruyter, Berlin, Germany.

Lal, R. 2000. Physical management of soils of the tropics: priorities for the 21st century. Soil Sci. 165:191-207.

Lal, R., and J. Ragland. 1993. Towards sustaining agricultural production in the tropics: research and development priorities. In: J. Ragland and R. Lal (eds.). Technologies for Sustainable Agriculture in the Tropics. ASA Special Publ. No. 56, Madison, WI, pp. 309-313.

Landon, J. R. (ed.) 1991. Booker Tropical Soil Manual. 2nd ed. Longman Technical and Scientific, Harlow, England.

Legros, J. P. 1992. Soils of Alpine mountains. In: I. P. Martin and W. Chesworth (eds.). Weathering, Soils and Paleosols. Development in Earth Surface Processes 2, Elsevier, Amsterdam, The Netherlands, pp. 155-176.

Loeppert, R. H., and D. L. Suarez. 1996. Carbonate and gypsum. In: Methods of Soil Analysis. Part 3. Chemical Methods. SSSA Book Series No. 5, Madison, WI, pp. 437-474.

Marschner, H. 1995. Mineral nutrition of higher plants. 2nd ed. Academic Press, London, England.

Martens, D. C., and W. L. Lindsay. 1990. Testing soils for copper, iron, manganese and zinc. In: R. L. Westerman (ed.). Soil Testing and Plant Analysis. 3rd ed. SSSA, Madison, WI, pp. 229-260.

Mengel, K., and E. A. Kirkby. 2001. Principles of Plant Nutrition. 5th ed. Kluwer Academic Press, Dordrecht, The Netherlands.

Mollaneda, R. P. 1988. A history of a local institution: the church of Baybay. Leyte-Samar Stud. (Divine World University, Tacloban City, Philippines) 12:71-82.

Myers, N., R. A. Mittermeier, C. G. Mittermeier, G. A. B. da Fonseca, and J. Kent. 2000. Biodiversity hotspots for conservation priorities. Nature 403:853-858.

Muhs, D. 2001. Evolution of soils on Quaternary reef terraces of Barbados, West Indies. Quat. Res. 56: 66-78.

Nakashizuka, T. 2004. The role of biodiversity in Asian forests. J. For. Res. 9:293-298.

Navarrete, I. A. 2002. Characteristics, Degree of Weathering, and Site Qualities of Two Highly Weathered Soils in Samar. Master of Science thesis, Leyte State University, Baybay, Leyte, Philippines.

Omura, A., Y. Maeda, T. Kawana, F. P. Siringan, and R. D. Berdin. 2004. U-series dates of Pleistocene corals and their implications to the paleo-sea levels and the vertical displacement in the central Philippines. Quat. Int. 115-116:3-13.

Rabenhorst, M. C., L. T. West, and L. P. Wilding. 1991. Genesis of calcic and petrocalcic horizons in soils over carbonate rocks. In: Occurrence, 
Characteristics, and Genesis of Carbonate, Gypsum, and Silica Accumulations in Soils. SSSA Special Publ. 26, Madison, WI, pp. 61-74.

Sanchez, P. A. 1976. Properties and Management of Soils in the Tropics. Wiley and Sons, New York, NY.

Schlichting, E., H. P. Blume, and K. Stahr. 1995. Bodenkundliches Practikum. 2nd ed. Blackwell, Berlin, Germany.

Schoeneberger, P. J., D. A. Wysocki, E. C. Benham, and W. D. Broderson. (eds.). 2002. Field Book for Describing and Sampling Soils. Version 2.0. NRCS, National Soil Survey Center, Lincoln, NE.

Scholz, U. 1986. Deforestation in the Asian tropics-causes and consequences. ASIEN, Deutsche Zeitschrift für Politik, Wirtschaft, und Kultur. Deutsche Gessellschaft für Asienkunde, Band 21, pp. 1-29.

Soil Survey Staff. 1999. Soil Taxonomy. A basic system of soil classification for making and interpreting soil surveys. 2nd ed. USDA-NRCS, Agriculture Handbook 436, US Government Printing Office, Washington, DC.

Sommer, M., and E. Schlichting. 1997. Archetypes of catenas in respect to matter-a concept for structuring and grouping catenas. Geoderma 76:1-33.

Srivastava, P. C., and U. C. Gupta. 1996. Trace Elements in Crop Production. Science Publishers, Lebanon, NH.

SWCF-CFTU-IGCI. 2005. Karst information kit for environmental management decision makers. Soil \& Water Conservation Foundation (SWCF), Cebu, Philippines; Conservation Farming in the Tropical Uplands (CFTU), Leyte, Philippines; and International Global Change Institute (IGCI), Hamilton, New Zealand.

Thomas, G. W. 1982. Exchangeable cations. In: Methods of Soil Analysis, Part 2. Chemical and
Microbiological Properties, 2nd ed. A. L. Page et al. (eds.). ASA and SSSA, Madison, WI, pp. 159-165.

Tisdale, S. L., W. L. Nelson, and J. D. Beaton. 1985. Soil Fertility and Fertilizers. 4th ed. Macmillan Publishing Co., New York.

Tsui, C. C., Z. S. Chen, and C. F. Hsieh. 2004. Relationships between soil properties and slope position in a lowland rain forest of southern Taiwan. Geoderma 123:131-142.

Ulrich, B. 1986. Natural and anthropogenic components of soil acidification. J. Plant Nutr. Soil Sci. 149:702-717.

Urich, P. B., M. J. Day, and F. Lynagh. 2001. Policy and practice in karst landscape protection: Bohol, the Philippines. Geogr. J. 167:305-323.

Urushibara-Yoshino, K., F. D. Miotke, and Research Group of Solution Rates in Japan. 1999. Solution rate of limestone in Japan. Phys. Chem. Earth, Part A Solid Earth Geod. 24:899-903.

USDA-NRCS, 1996. Soil survey laboratory methods manual. Soil Survey Investigation Report No. 42, Version 3.0. USDA-Natural Resources Conservation Service, National Soil Survey Center, Lincoln, NE.

Verstappen, H. Th. 1997. The effect of climatic change on Southeast Asian geomorphology. J. Quat. Sci. 12:413-418.

Westerman, R. L. (ed.). 1990. Soil Testing and Plant Analysis. 3rd ed. SSSA, Madison, WI.

WRB, 1998. World Reference Base for Soil Resources. World Soil Resources Report 84, ISSSISRIC-FAO, Rome, Italy.

Yaalon, D. 1983. Climate, time, and soil development. In: L. P. Wilding, N. E. Smeck, and G. F. Hall (eds.). Pedogenesis and Soil Taxonomy I: Concepts and interactions. Elsevier, Amsterdam, The Netherlands. pp. 233-251. 